\title{
Wellness Tourism-New Challenges and Opportunities for Tourism in Salou
}

\author{
Marta Gemma Nel-lo Andreu ${ }^{1}$, Alba Font-Barnet ${ }^{1, *(D)}$ and Marc Espasa Roca ${ }^{2}$ \\ 1 GRATET, Department of Geography, Rovira i Virgili University, 43480 Vila-seca, Spain; \\ martagemma.nello@urv.cat \\ 2 Tourist Board of the City Council of Salou, 43840 Salou, Spain; mespasa@salou.cat \\ * Correspondence: alba.font@urv.cat
}

Citation: Andreu, M.G.N.-1.;

Font-Barnet, A.; Roca, M.E. Wellness Tourism-New Challenges and Opportunities for Tourism in Salou. Sustainability 2021, 13, 8246. https:// doi.org/10.3390/su13158246

Academic Editors: Carlos Costa, Joana Alegria Quintela and Joaquim Gonçalves Antunes

Received: 7 June 2021

Accepted: 12 July 2021

Published: 23 July 2021

Publisher's Note: MDPI stays neutral with regard to jurisdictional claims in published maps and institutional affiliations.

Copyright: (c) 2021 by the authors. Licensee MDPI, Basel, Switzerland. This article is an open access article distributed under the terms and conditions of the Creative Commons Attribution (CC BY) license (https:// creativecommons.org/licenses/by/ $4.0 /)$.

\begin{abstract}
Following a long history of using various strategies and policies for diversification and seasonal adjustment in the face of the challenges of achieving economic, social, and environmental sustainability, sun and beach destinations should also consider targeting the wellness tourism market as a post pandemic opportunity and long-term solution. Salou is a mature sun and beach destination in the Mediterranean, but one which, for some time, has had an increasing commitment to family and sports tourism as a result of a strategic renewal process. Now, with the impact of the coronavirus pandemic, the destination management organization is considering the evolution of the model, the internalization of sustainability as a fundamental value, and the impact of different markets. In this study, we examined the challenges the Salou Tourist Board has faced during the development of a post pandemic model for sustainable tourism and what strategies it has adopted in response. We also considered the opportunities and competitive advantages that Salou has in the field of wellness tourism. The results obtained should encourage the continuation of work that promotes the environmental axis of sustainability and adds value to the natural resources on which it depends, including the sea and the landscape, while maintaining the environmental quality of the resources.
\end{abstract}

Keywords: pandemic consequences; destination management; innovative strategies; wellness tourism; Salou; coastal destination

\section{Introduction}

In the tourism sector, changes in demand occur quickly, often at a rate that far outpaces a destination's ability to transform itself and adjust to new market trends [1].

The COVID-19 crisis has paralysed a large part of the economy, and tourism has been one of the most heavily affected sectors. In 2020, world tourism experienced the worst year on record, with international arrivals falling $74 \%$ according to the latest figures from the World Tourism Organization [2]. Changes in travelling and tourism are inevitable, considering the combination of business and healthcare regulations, changes in consumer choices, patterns of mobility around the world, and availability of destinations [3,4].

In 2020 and 2021, many questions have been raised about how to relaunch tourism activities and the possibility of the tourism model evolving; this period has offered an opportunity to rethink and redevelop tourism as an asset of change towards more resilient and sustainable destinations. Indeed, this was already a topic of debate before the pandemic $[5,6]$.

According to the consultancy firm Agencia de Desarrollo, Ideas y Turismo (ADEITUR) (Development, Ideas and Tourism Agency), the key approach is to position destinations as $4 \mathrm{~S}$ destinations, i.e., destinations that are sustainable, safe, sanitary, and in solidarity. These are tourist destinations that cooperate with the operating companies and producers, look after their workers, allow the local population to be involved in tourism activities, value their heritage, and implement measures to provide tourists with security, healthcare, and safe environments. In short, they are humanised destinations [7]. The current situation 
related to the pandemic has accelerated trends in tourism that were already taking hold in the sector: a growing preference for less crowded places; holistic and wellness experiences; and innovative tourism products that consider future generations, are more aware of sustainability, and respond to the new paradigm of heightened global attention to caring for and respecting the planet and humanity [8].

Although diversifying tourism products without sacrificing established excellence in sun and beach products is a strategy within the reach of few competitive destinations, it can nevertheless be a wise approach, provided that tourist products are fully articulated and appreciated [9]. Following their long history of considering strategies and policies for diversification and seasonal adjustment in the face of the challenges of achieving economic, social, and environmental sustainability, sun and beach destinations should also consider targeting the wellness tourism market as a post pandemic opportunity and long-term solution to those challenges.

In this article, we describe actions and strategies designed by the Salou Tourist Board, which have been accelerated by the COVID-19 pandemic, as well as the advances achieved within a provincial research project carried out during the months of November 2020 and June 2021 entitled "Well-Being Tourism: Co-Creating Tourist Experiences". The general aim of this project was to give value to natural, cultural, and food and wine heritage to turn tradition into novelty. The project involved the determination of the potential for the facilitation of this goal in the multidimensionality of wellness in the Tarragona province in south Catalonia. This province is distinguished by its numerous and varied tourist areas that form a mosaic of landscapes both along its coast and inland, its tangible and intangible heritage, its gastronomy, which is based on quality local produce, and many other attractions that need to be rediscovered and seen from a different perspective.

The project we describe here sought to offer tools for sustainable local and regional development through the co-design of tourist experiences, inspired by the potential of the land and wellness products. Two protected natural areas in the south of Catalonia were taken as case studies, and Salou, which is the focus of this article, was used as an example of a coastal tourist destination with a traditional tourism model based on sun, beaches, and leisure, but which is designing a strategy to respond to emerging trends including sports tourism and, more recently, wellness tourism.

This study aimed to answer the following research questions:

R1: What challenges has the Salou Tourist Board faced in developing a post pandemic model for sustainable tourism and what strategies has it adopted in response?

R2: What opportunities and competitive advantages does the tourist destination of Salou have in the field of wellness tourism?

\subsection{Diversifying Sun and Beach Destinations - A Path to Sustainability and Competitiveness}

At the end of the 1980s, sun and beach destinations began to face various challengesovercrowding, unsustainability, degradation, and a loss of attractiveness - that required new formulas to achieve quality, sustainability, excellence, and competitiveness in territorial planning and tourism management [10].

According to the authors of [11], the transformations experienced by many such destinations were the consequences of three types of strategies or policies, some of which are still in force today. The first strategy, which emerged in the 1980s, focused on renewing destinations and improving the quality of tourist establishments. The second, beginning in the 1990s and continuing into the early 2000s, sought to incorporate new leisure and recreational products, as well as new equipment and activities (e.g., golf, nautical activities, conferences and congresses, gastronomic and cultural offerings, and thematic tourism) in order to enrich the offerings for tourists, break with seasonality, increase the attractiveness of destinations, transform destinations' images, and create new business opportunities [12,13]. The third strategy - the sustainability strategy-was first applied in the mid-1990s and is still being applied today. It aims to protect and enhance natural and 
cultural attractions, as well as implement instruments for environmental management and control.

In the 21st century, tourism has been shaped by profound structural changes in the sector that have shifted the focus to meeting increasingly diverse demands. Beyond passive stays in the sun, tourists today are interested in engaging in various athletic and sport activities, increasingly appreciate contact with nature, and, above all, value the availability of recreational offerings and facilities [10]. For many coastal tourist destinations, the strategy for the stagnation/exhaustion phase of their tourist life cycle has been to configure offerings that complement traditional sun and beach products in order to satisfy the new motivation of tourists, that is, to transform their trips into life experiences [14,15].

To meet those demands, tourism renewal requires a strategic vision that galvanises political, business, and social consensus; gives special importance to social agents, both in how destinations are perceived and needs identified; and prioritises the equitable distribution of responsibilities and benefits [11,16,17].

Those trends have directly affected traditional sun and beach destinations, some with more than 50 years of experience in the industry, as is often the case with Spain's coastal destinations. In Spain, the recently proposed Tourism Sustainability Strategy for Destinations, which will receive 1.9 billion euros in funding over the next three years, seeks to lay the foundations for a new tourism model based on environmental, territorial, social, and economic sustainability. As Spain's sun and beach destinations currently face a profound paradigm shift in how to remain viable, the strategy seeks to increase their competitiveness by reinforcing variety in tourist experiences and managing those experiences with digital tools and continually increasing standards.

In 2019, coastal tourist activity in Catalonia, the Balearic Islands, Valencia, Murcia, Andalusia, and the Canary Islands generated a turnover of 108 billion euros and 1.6 million jobs, which represented $70.5 \%$ of the total tourism GDP that year [18]. In the same year, excluding large cities, 733 coastal towns in Spain possessed 63\% of the country's capacity in terms of tourist accommodation and attracted $65 \%$ of its total tourism demand.

Catalonia, a top tourist destination not only in Spain but at the international level, received 39.4 million tourists in 2019 and hosted 84.1 million overnight stays, $84.7 \%$ of which were from abroad, and made 25.166 billion euros in revenue [19]. Tourist offerings in Catalonia comprise more than a million accommodations, which, in 2019, represented $22.1 \%$ of all accommodations in Spain and $2.5 \%$ of all accommodations in the European Union, excluding housing used by tourists. However, in 2020, due to its great dependence on foreign visitors, none of whom could enter due to COVID-19 restrictions, Catalonia experienced a $70 \%$ reduction in overnight stays and a corresponding drop in revenue [20].

\subsection{Wellness as a Strategy in Coastal Destinations}

Wellness has long been a philosophical and sociological concern, and gradually, research has spread to subject areas such as psychology, health science, and economics, among others [21]. However, tourism studies have also focused more on wellness in recent decades from both a theoretical and methodological perspective, creating tourist experiences based on wellness [22]. As defined in the report of the World Tourism Organization and European Travel Commission [23], health tourism encompasses tourism undertaken, with the main motivation being to contribute to physical, mental or spiritual health through medical and wellness activities. However, as noted by the Global Wellness Institute (GWI), the catch-all term "health tourism" is used to describe both medical and wellness tourism modalities from surgery to yoga retreats [24].

The GWI [24] defines wellness as "the active search of activities, options and lifestyles that lead to a holistic state of health". Accordingly, wellness is not a passive state, but instead, an "active exercise" associated with intentions, options, and actions as people work towards an optimum state of health and wellness. Wellness is related to holistic health, which has many different dimensions (physical, mental, environmental, spiritual, emotional, and social) that should work together in harmony. Within the context of an 
integrative and holistic wellness tourism, these three elements could lead to holidays that provide a combination of 1) pleasure and hedonism, 2) altruistic activities, and 3) significant experiences [21].

Wellness is an engine of economic growth, responsible for job creation, promotion of local produce and denominations of origin, and empowering women. Wellness is related to health practices and can help recover traditional wellness methods, and reduce the mental health epidemic. Wellness also plays a role in protecting natural and cultural assets, supporting environmental protection and promoting sustainable tourism. In short, wellness improves quality of life and social capital [25].

Wellness tourism in coastal destinations with a long history of sun and beach tourism, and which are not protected areas, may not seem well matched. According to [26], a large amount of research has focused on the benefits of wellness tourism for the local area, exposing "green" areas such as parks and protected areas [27-30], with less attention given to the specific benefits of "blue" areas and coastal environments.

Coastal wellness refers to the improved wellness directly associated with being near (living or visiting) the sea or taking part in activities in or next to the sea [31]. The sea, coast and beach are key places for tourist actions and experiences. The affective forces we find in maritime environments imply a sensorial commitment to sight, smell, touch, and emotion [32].

\section{Materials and Methods}

The methodology applied in this research was based on a process of complete and transversal co-creation between the research team and the Salou Work Group (SWG), with the latter generating the data and designing the products resulting from the research.

SWG has 14 participants and was created jointly by the research team and the Salou Tourist Board. Participants had to be related to the field of tourism and wellness following the four large groups known for "Key Wellness Tourism Stakeholders" by GWI [24]. According to this classification, SWG is made up of 4 participants in Hospitality and Tourism Infrastructure ( 2 restaurants, 1 golf resort and 1 nautical park), 4 participants in Wellness Lifestyle (1 fitness club, 1 mind-body studio, and 2 representatives of triathlon groups and events), 2 participants in Wellness and Prevention (2 CAM and integrative health centres), and 4 participants of Government at the council level (2 representatives from the Tourism Promotion department, 1 from Family and Community Medicine, and 1 from Environment).

We developed a method that included visual models for both the data gathering and analysis stages, using virtual and in-person techniques, based on the following stages:

1. Fieldwork, as a previousand transversal stage throughout the methodological process. Our approach was based on immersion, with some members of the research team spending time in the study area to obtain the necessary information and data to understand the destination, identify the key stakeholders, and perceive the tourist model and challenges Salou faces.

2. With visual and virtual collaboration platforms, the objective of the first session was to detect the resources in Salou, as well as the potential synergies and collaborations between agents and tourist destinations in the territory, both linked to the wellness trend.

3. We designed a technical training program specialising in the new trends and benefits of wellness applied to tourism. Specific training of territory agents by experts was carried out in the following areas: mindfulness, woodland bathing, natural support for health, sport, wild gastronomy, medicinal plants, analysis and interpretation of territory resources, and tools and techniques for innovation and creativity. This training, which was subsidised by the project, was aimed at members of the worktables.

4. We used a workshop to co-design tourist experiences in wellness via a dynamic session of mental maps, visual thinking, and meditation for creativity addressed to SWG participants. This session was carried out by the project's research team, with 
a consolidated track record in experience design, an expert in creativity skills and visual thinking, and an expert in meditation.

The results obtained from these methods, as well as through close co-operation with local tour managers, are included in this article.

\section{Salou Tourist Destination}

Salou is a town located in Catalonia, in the north-east of the Iberian Peninsula, which borders the Mediterranean (Figure 1) by a unique geographical feature that has conditioned its entire history, the Cape of Salou. It is a pleasant and interesting coastal area for sailing, which made it the starting point for several historic naval adventures, such as the conquering of Mallorca by Jaume I (1229), which was a significant moment in the history of the Mediterranean. It has also been used as a shelter for pirates between the 15th and 17th centuries, the location of numerous military defence buildings during the wars in the 20th century, a port for many fishermen, and, in recent decades, a destination for millions of tourists. The origin of tourism in the town is associated with the discovery of the therapeutic properties associated with the sea and bathing, which attracted groups of people who wanted to enjoy this healthy environment.
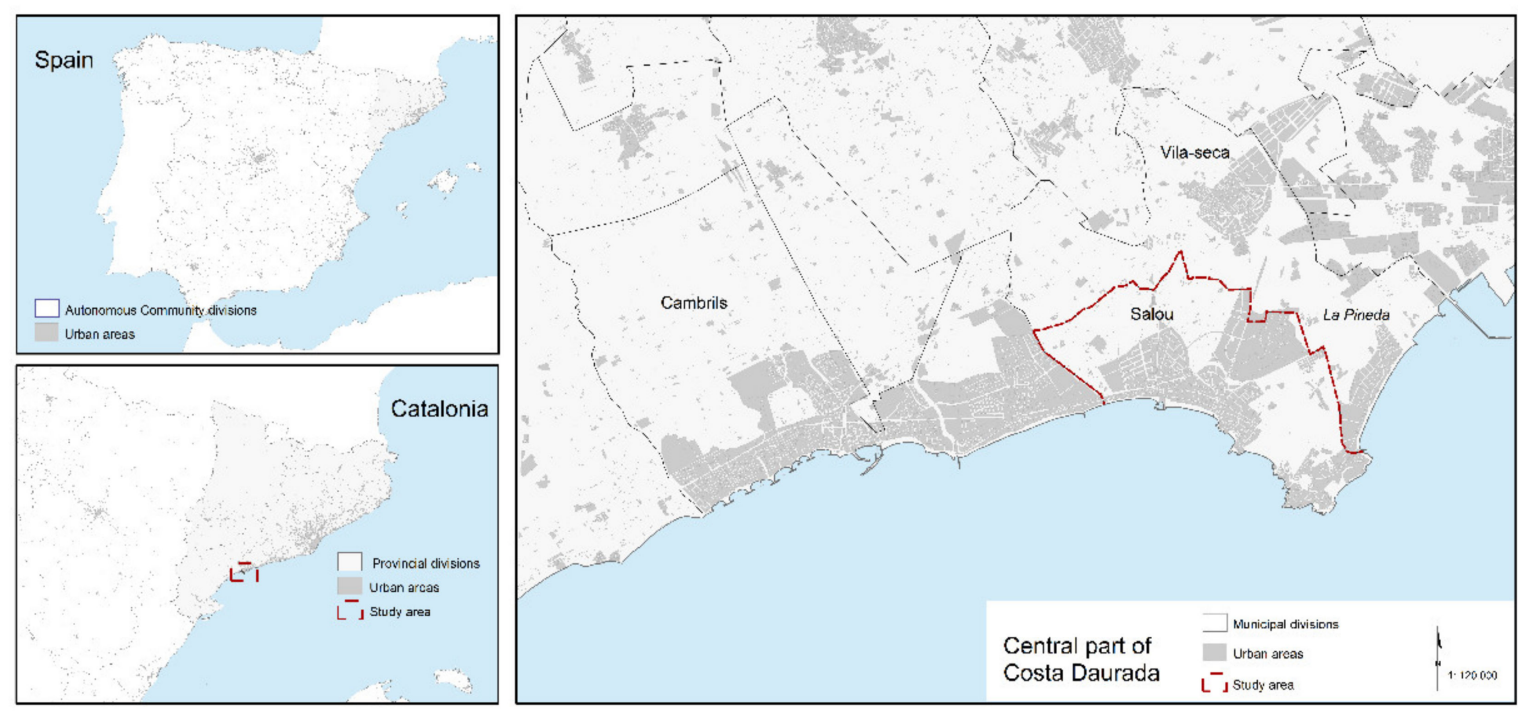

Figure 1. Location map of the study area. Source: own elaboration, 2021.

With more than 2 million visitors a year accounting for more than 8 million overnight stays (data from 2019 provided by Salou Tourist Board), concentrated mainly in the summer period, Salou is one of the main sun and beach destinations in Spain. This traditional tourism model has been complemented for more than 25 years by the offer of entertainment, supported mainly by the presence of Port Aventura World, Spain's leading theme park, and one of the most popular throughout Europe.

However, the traditional model continues to characterise the destination and its main attractions. Salou's beaches $\left(0.2 \mathrm{~km}^{2}\right)$ continue to be its main attraction, with the level of excellence manifested in the annual certifications that recognise the quality of the water and the provision of complementary services. The coastal diversity, with nine environments ranging from huge beaches with fine, white sand, to small rocky bays and natural bathing areas, means that Salou offers visitors a unique experience in comparison to nearby destinations. These areas also offer leisure opportunities, with a wide-scale offer of marine activities for all visitors.

With average temperatures of more than $15^{\circ} \mathrm{C}$, the climate provides the necessary comfort for enjoying the outdoors, and is one reason why the main activity for tourists in the destination is walking. This is also partly a consequence of town planning, with large walkways by the sea. The popularity of walking has caused town planners to try to gain 
further space for the mobility of people and sustainable vehicles, to the detriment of motor vehicles.

It is in international markets, particularly in Europe, where Salou finds most of its visitors, who are mostly from France, the United Kingdom, Ireland, Benelux, Russia and eastern Europe. They find that the area offers good communication over land $(300 \mathrm{~km}$ connection with France by road), by sea (the port of Tarragona is $10 \mathrm{~km}$ away and the port of Barcelona $100 \mathrm{~km}$ ), and by air (Reus airport is $10 \mathrm{~km}$ away and Barcelona airport $80 \mathrm{~km}$ ).

Most of the hotel accommodations have been renovated in recent years and there are three top quality campsites, which makes accommodation one of the main attractions for families who can find affordable prices and pleasant environments adapted to their needs. There are 57,136 places in hotels, hostels, apartments and campsites, which more than doubles the local population of about 28,000 inhabitants to a potential of 140,225 inhabitants in high tourist season, after taking into account second home owners as well (data from 2020 provided by Salou Council). This shows the importance of the tourism industry for the town.

Salou seeks official certification to accredit its services and highlight its credibility. More than 18 years ago, it became the first Catalan destination to be certified as a Family Tourism Destination. This provided an impulse for the destination, as it found a clear position to identify with and to promote a large part of the town's private and public offerings.

Salou has also been certified for football, sailing, golf, and cycling tourism, and soon will also receive certification for triathlons, so as to offer excellent conditions for practising, competing, and watching sport. Accordingly, the town offers multiple options for enjoying amateur exercise, such as long bicycle lanes and large pedestrian areas for running, professional international competitions for triathlons, golf, sailing and football, and well-known events watched by a large international audience, such as the Costa Daurada rally, which is part of the World Rally Car world circuit.

Finally, Salou was one of the first towns to join the DTI network (Smart Tourist Destinations) to continue its improvement by including sustainability as one of its five cornerstones.

\section{Results}

In this section, we describe the actions and strategies designed by the Salou Tourist Board in terms of offers, services, markets, and segments, which outline the roadmap for continuing to innovate and be competitive, where wellness and nature have a greater role than in the sun and beach model. First, we analysed the current tourism offer, as well as the resources available in Salou that offer opportunities for new products and wellness experiences.

\subsection{Challenges in Salou during the Pandemic}

As a result of the recent pandemic, new reasons for travelling that generate opportunities are becoming established. According to a recent study on the impact of COVID-19 in the Spanish tourism sector, it has been detected that people are more aware of the importance of health, and are looking for holidays with more specific benefits for physical and emotional wellness [33]. However, some destinations, such as Salou, had already started working on this long before the pandemic. Salou began a comprehensive remodelling process in 2019. This included recovering its landscape and environment assets, giving value to the area's history, redistributing business and generating wealth through tourism, and looking for new market niches that reduce seasonal fluctuations in tourism that lead to an extreme peak in activity from June to September [34].

During the pandemic, travel restrictions have been a considerable blow for Salou as they have made it impossible for foreign visitors to arrive. This has affected the promotional activities on all levels, and has even modified Salou's tourist brand, which, for a few months, removed the baseline that accompanies its logo "Europe's beach", because of the 
incoherence of the meaning and because it was an inappropriate connotation in the middle of a pandemic.

In recent months, promotion of the destination has focused on making an extra effort to reinforce an approach initiated in recent years, i.e., highlighting the destination's natural and sustainable side. This is an ambitious objective as it implies changing people's perception, and it has therefore been planned as an evolution of the resources that the public are already familiar with.

Salou's natural aspects are supported by recognised assets such as its beaches, together with new incentives including gastronomy, the landscape, and historic places, which are identified as the main resources for development and differentiation. Therefore, attempting to boost the value of the natural environment and reduce the seasonality of tourism, wellness has been earmarked as an opportunity to offer a differential added value that is coherent with the identity of the destination and its current resources, while maintaining coherence with the foreseeable new motivations for tourism in the post-COVID-19 era.

Since the beginning of the pandemic, the Salou Tourist Board has understood that the context calls for change and it has decided to create the "REPTTES" program (the CHALLENGES program), which comes from REactivació i Promoció del Teixit Turístic Empresarial de Salou (Reactivation and Promotion of the Business Tourism Sector of Salou). Relying on the involvement and commitment of businesses, this program provides a roadmap to address the current situation, and presents a firm attitude at a time when uncertainty reigns.

The main points that the document presents are as follows:

- Evolving the current tourism model by consolidating the existing cornerstones (sun, beach, and leisure), developing associated attractions (mobility, gastronomy, sport, and heritage), and adding a new health and nature aspect.

- Fostering sport and creating new products to reduce the seasonality of tourism.

- The relationship with markets according to their mobility vis à vis the town, identifying neighbouring markets (in geographic terms) with historical links and establishing a differentiated promotion strategy.

- Determining the collaborative work (e.g., with entities, organisms, and companies) that is essential for each project.

- Identifying possible new drivers that can motivate travellers to visit.

- Assuming the idea of improvising as part of the work system-an idea invented internally, to define the need to constantly adapt according to the environment.

- When devising new projects and products, they must be accessible for all people, coherent with strategic programs, innovative (adding value), and sustainable, supporting development in balance with the environment.

\subsection{Analysis of the Potential of the Destination in Wellness Tourism}

According to [35], to have the capacity to become or remain attractive for wellness tourism, destinations need security, good prices, nature-based activities, cultural attractions, a temperate climate, traditional therapies, healthy local cuisine, authenticity, sustainability, low levels of pollution, and health tourism facilities, services, and experiences. However, in many cases, the articulation of resources defining health tourism proposals has been based more on the destination's strategic vision than on the resources themselves [36]. In the Report on the results of monitoring the competitiveness of Spanish sun and beach destinations, which looked at 15 sun and beach destinations in Spain [37], Salou was ranked 7th. It is also interesting to highlight its 2 nd place position within the wellness indicator regarding the cornerstone of diversification and support for leisure activities.

With regard to accommodation, complementary offers can be found in less than half of the options, and they are usually focused on aspects of swimming pools, and are always unremarkable. Of the 23 four- and five-star hotels in the destination, 13 have spa services and treatments, but they are a complementary service and not an attraction factor.

The catering sector, which has gained prestige and diversity within the town, does not include a particularly healthy offer, although it is true that Mediterranean cuisine is 
closely linked to health and wellness, and there is good quality food available in many establishments. However, it is surprising that there is no specific gastronomy sector focused on natural wellness, bearing in mind the link to sport.

As for other sectors, beauty salons and gyms are usually the places that offer more diversity in this respect, and even include concepts of holistic aesthetics that work on personal wellness from multiple perspectives such as meditation and mindfulness, etc. This is the case of "Estètica Holística Beti Martí", which is well-established in the business sector of Salou, having existed for 25 years.

We did not find any specific examples of unique tourist experiences under the conceptual umbrella of wellness, even though we could relate many visits or activities to this concept.

Supporting sport as the town's main opportunity to reduce the seasonality of tourism is widely supported by the private sector, which provides top-level infrastructure, making Salou a unique environment in which to enjoy sport at different levels.

Current sporting locations include the Football Salou sport complex, which has 15 competition pitches and is used by more than 20,000 athletes a year; the Salou Yacht Club, where several national and international champions in various nautical disciplines started their careers; and Lumine Golf Club, which was recently recognised as the best golf venue in Europe. These locations represent an excellent sport offering which is complemented by the destination itself. In the town, we found three sport pavilions, a swimming pool, a circuit for all-terrain bikes, and three football pitches. The maritime environment is also recognised as a place to enjoy sport, for example, with routes open for swimming and triathlons. The town plan of action for tourism explains that "we understand the destination to be a huge sports stadium", as it has the facilities, natural resources, and layout to provide excellent sport services. Furthermore, this vision has the support and participation of the public administration (Town Hall and Tourist Board) and private business sector.

According to [35], Salou has different characteristics regarding its blue area and the potential this possesses, ranging from nautical facilities and the offer of services such as sailing and light sailing, surfing, sea trips and diving to excellent beach management, accessibility, and leisure value. The beach, Mediterranean Sea, and Cape of Salou are seen as natural blue areas with multidimensional benefits for wellness. The research participants highlighted potential in terms of the benefits the blue areas could bring the destination. Society considers coastal areas ideal places for healthy living. Living near blue areas and using these places contribute to an improved state of mental well-being, and with that, there is a greater probability of doing physical activity and having a less sedentary lifestyle.

Consequently, these blue areas are complemented by infrastructure such as bike lanes, viewpoints, bird hides and the Camí de Ronda coastal path (6.5 km long).On a historic level, the Camí de Ronda coastal path was used for sea surveillance and by fishermen, and now, with the recovery of this path, it is possible to walk along the coast and see sites that have been impossible to access for many years, revealing Salou's natural assets and landscape. Besides the different panoramic views that you can discover along the route, the path passes beaches and bays, making it a unique way to discover the Cape of Salou.

Discovering the area through the landscape is a form of renewal. This mode of tourism complements the main sun and beach model of tourism, with its own different resources [38]. Other services and facilities-the hotels, sailing club, first class sport facilities, integral and holistic medicine centres, the botanical park (currently not operational) - give this destination a solid and diverse basis for delivering wellness experiences.

When considering the intangible nature of the destination, the members of SWG highlighted the following characteristics found in Salou that provide wellness, particularly outside the summer peak tourist season: the year-round mild temperature, autumn and winter sunsets, peacefulness, the soundscape, smelling the sea first thing in the morning, tranquillity, calmness, the local culture, and Mediterranean gastronomy. 


\subsection{A Proposal for New Wellness Experiences}

As a result of the final participatory workshop of the project with the SWG, four experiences were designed (see Table 1). This consisted of a $3.5 \mathrm{~h}$ workshop using mental maps to determine the basis of wellness tourism experiences, applying visual thinking to gather the information from the session, and guiding a meditation session to spark creativity.

Table 1. Summary of the designed wellness tourism experiences. Source: own elaboration, 2021.

\begin{tabular}{|c|c|c|c|}
\hline \multicolumn{4}{|c|}{ Title } \\
\hline "Sea, Music and Soul" & “Walk Your Senses" & "Open Up to Life" & "Disconnect to Connect" \\
\hline \multicolumn{4}{|c|}{ Description } \\
\hline $\begin{array}{l}\text { Listening to different styles of } \\
\text { music at sunset while } \\
\text { pondering the sea and } \\
\text { activating the senses of sight, } \\
\text { hearing, and taste }\end{array}$ & $\begin{array}{l}\text { Guided route through a } \\
\text { botanical garden to experience } \\
\text { and ponder the change in } \\
\text { seasons; healthy cooking } \\
\text { demonstration with local chef; } \\
\text { experiences focused on water, } \\
\text { music, comfort, tranquillity, } \\
\text { connecting with nature, and } \\
\text { silence (restricted to four } \\
\text { times a year) }\end{array}$ & $\begin{array}{l}\text { Guided meditation at sunrise } \\
\text { for an improved life } \\
\text { experience, heightened } \\
\text { awareness of what one } \\
\text { already has, and a greater } \\
\text { sense of the value of the good } \\
\text { things that life offers }\end{array}$ & $\begin{array}{c}\text { Meditation session on } \\
\text { paddleboards and free } \\
\text { snorkelling session to value } \\
\text { the sea as a tool for } \\
\text { meditation, with a focus on } \\
\text { weightlessness, relaxation, } \\
\text { and connecting with all of the } \\
\text { senses }\end{array}$ \\
\hline
\end{tabular}

\begin{tabular}{|c|c|c|c|}
\hline \multicolumn{4}{|c|}{ Location } \\
\hline $\begin{array}{c}\text { Cala Crancs, Cala Forn, Hotel } \\
\text { Negresco, and Hotels Cap } \\
\text { Salou }\end{array}$ & A botanical garden & $\begin{array}{l}\text { Fine-sand beaches at Llarga, } \\
\text { Llevant, and Ponent }\end{array}$ & Penya Tallada Beach \\
\hline
\end{tabular}

Target markets and group size

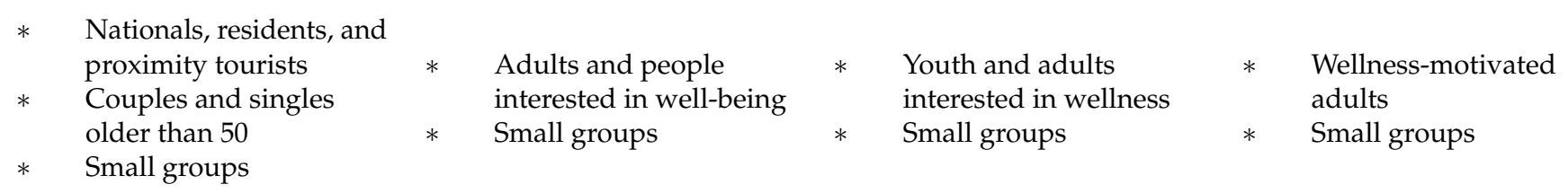

\begin{tabular}{cccc}
\hline & \multicolumn{2}{c}{ Seasonality } \\
\hline Spring and autumn & At every change of season & Summer, spring, and autumn & Summer, spring, and autumn \\
\hline
\end{tabular}

The design of experiences aims to provide a complementary offer of wellness activities based on the resources that the destination has, which are primarily related to the sea, coast, and benefits of blue spaces. We also considered the botanical garden, a municipal resource that is currently closed and in disuse. All experiences require collaborative work between the local administration, tourist agents (hotels, restaurants, and nautical clubs), and local experts in meditation, holistic wellness, and therapy.

\section{Discussion}

Salou Tourist Board has proposed a set of actions to become a sustainable destination and to move away from a model based only on sunshine, beaches, and leisure. The destination is working to develop markets for sports and fitness as well as healthy gastronomy, and to revalue green and blue spaces. Such efforts have been reflected in the CHALLENGES program as a fast response to suit the post pandemic period.

The role that wellness can play in the current tourism offering opens up a series of opportunities, mainly due to its limited current presence, but also due to the known potential of the town's tangible and intangible resources. The explanation behind the current lack of wellness offering may lie in the traditionally generalised demand, meaning it has not 
been necessary, until now, to look for a differential value or search for specific incentives to attract tourism. Salou has strengths, including security, good prices, a temperate climate all year, and coastal landscapes that have recently received aid for maintenance and recovery and that are the basis of activities that can be linked to increased well-being. In addition, the high-quality sport equipment and services have led to Salou being certified as a sports destination and will undoubtedly help reinforce Salou's image as a destination for wellness tourism. Our analysis revealed that, despite some important restaurant offerings based on Mediterranean cuisine, it is necessary to enhance the culinary benefits available. From the evaluations of the participating agents, it was clear that Salou offers tranquillity, especially during spring and autumn, which makes it possible to articulate interesting proposals to adjust the destination's image seasonally and improve its sustainability.

Some resources are not being used effectively, such as the botanical garden, a twohectare green space created in 2009 as an innovative place that currently does not offer the functions for which it was known (recreation, walks, relaxation, and opportunities for social interaction). Undoubtedly, it has high potential, as highlighted by the experiences proposal. It could be a managed area of great interest to local people and nearby urban centres for environmental education activities and wellness experiences.

The coastal path is one of the great prospects for the destination if the required actions of maintenance, recovery and environmental restoration of the coastal landscape and the natural environment can be completed. It offers multiple possibilities related to wellness activities, environmental education, and sports. This still needs to be incorporated into the promotion and image of the destination.

Wellness is now being explored by the destination as a tourist attraction in order to evolve its tourism model and provide an inspirational example that stimulates support from the private business sector. Salou has tangible and intangible resources that provide integral benefits to the health of residents and the tourist population. The benefits of the sea, coast, and the beach are the basis for creating new wellness experiences, which have to align with available infrastructure (sport, aquatic, integral medicine, fitness and body studios, etc.) that can enable their implementation. However, the main challenge is detecting market niches interested in wellness that are looking to utilise differential products and services with high added value in this destination.

As for local politics, this is focusing on supporting and developing products and experiences linked to wellness to prove that tourism is a driving sector that offers benefits to different economic sectors and agents (beauty centres, gyms, catering businesses, the agricultural sector).

One proposal transferred to the agents of the destination involves designing a platform or space to promote the development of wellness and holistic tourism, give visibility to the sector's associated companies and experiences, attract quality tourism, and reduce the seasonality of tourism. The strategy is already being implemented in nearby sun and beach destinations including Costa Brava Pyrenees (i.e., its recent creation of the Health and Wellness Marketing Club) and Ibiza (i.e., its E Wellness platform). Both public and private agents believe that wellness tourism can improve innovation, providing a competitive edge and helping to reduce seasonality. Salou's tourism sector should look to create synergies between tourist sector actors, trade, and integral and holistic medicine centres, and seek the involvement of citizens residing in the destination and the network of small companies operating in the territory.

The results of this project indicate benefits directly associated with the area, where networking and involving local agents are key to defining new tourist experiences and strategies that respond to new trends and the current situation, where tourism has to be boosted in the post-COVID-19 era, with wellness and safety at the centre of this.

The process of the project and the results obtained encourage continuing work that promotes sustainability and adds value to the natural resources on which it depends, including the sea and landscape, while maintaining the environmental quality of the resources [39]. At present, with all the documentation, analysis and information obtained 
from the first two stages of the project, the third stage is just beginning, for which the results obtained will be applicable to most of the public and private agents in the destination, and they will be of scientific interest for another article.

\section{Conclusions}

The tourism sector has been one of the most severely affected by the COVID-19 pandemic. The current year, 2021, will still be a year of recovery. However, it is true that faced with these complicated situations, with such serious negative consequences for society and tourist destinations, local politics play an important role. One example is the case of the tourist destination Salou. When faced with a crisis, it is necessary to foster sustainability and politics sympathetic to current needs, co-participatory governance, and to work towards segmentation and reducing the seasonality of tourism in order to enhance the tourist attraction towards a quality experience without overlooking what makes it unique [7].

Supporting wellness tourism can be used as a strategy to give value to an integral relationship between different economic sectors at a destination. There are numerous opportunities associated with tourism and the wellness sector and all kinds of services, infrastructure, and facilities that can help companies stand out, provide more value, and attract higher spending by travellers. In addition to wellness experiences, wellness tourists need transport, food and accommodation, and they probably will look for shopping or entertainment as well. All these businesses, whether they are specific to wellness or not, benefit from wellness tourism and are part of the wellness tourism economy.

The pandemic has forced many sun and beach destinations along the Spanish coast to adapt, but it is also important to emphasise that this adaptation requires supra-municipal investment. Sun and beach destinations in Spain, including Salou, have shown interest in opting for Next Generation European funds.

Our study revealed a relative lack of integrative knowledge about wellness in the tourist sector of Salou, reason why the research project offered a training on wellness tourism to the participants. To that end, initial worktables sessions were held virtually, although this limited the quality and amount of information that could be obtained. Among other challenges, hoteliers have little presence in the SWG.

To date, few studies have positioned wellness tourism as a tool for addressing the challenges of achieving sustainability that face longstanding sun and beach tourist destinations, which have typically led to the overuse of resources, tourist overcrowding, and marked seasonality in visitor numbers.

The well-being that coastal destinations and blue infrastructure offers is another research topic that, despite gaining traction, requires a deeper examination to specify and compare the well-being societal benefits with different coastal areas and to promote new proposals for experiences aimed at a destination's residents and tourists alike. Beyond that, researchers need to gauge the social impact on the destinations as a means to promote spaces for debate with local stakeholders about new strategies for well-being and environmental, social, and economic sustainability.

Author Contributions: Introduction and Materials and Methods, M.G.N.-1.A. and A.F.-B.; Salou Tourist Destination, M.E.R.; Results, Discussions, and Conclusion, M.G.N.-1.A., A.F.-B., and M.E.R. All authors have read and agreed to the published version of the manuscript.

Funding: This research and APC was funded by Diputació de Tarragona and University of Rovira I Virgili, under the grant WELL-BEING TOURISM. CO-CREATION OF TOURIST EXPERIENCEST20253S, and by the Spanish Ministry of Science, Innovation and Universities (AEI/FEDER, EU) under the grant CHORA-CSO2017-82411.

Acknowledgments: We would like to thank the Tourist Board of the City Council of Salou, and the Department of Research and Universities of the Catalan Government (FI Grant).

Conflicts of Interest: The authors declare no conflict of interest. 


\section{References}

1. Perelli del Amo, O. Ordenación territorial y turismo, en un nuevo escenario para el turismo. Rev. Econ. 2002, 92, 55-66.

2. UNWTO. COVID-19 and Tourism | 2020: A Year in Review; UNWTO eLibrary: Madrid, Spain, 2021.

3. Euruni. What Will Happen With Tourism for the Rest of 2020? Travel Trends after the COVID-19 Pandemic. 2020. Available online: https: / www.euruni.edu/blog/tourism-2020-travel-tr (accessed on 4 February 2021).

4. Spalding, M.D.; Burke, L.; Fyall, A. Covid-19: Implications for nature and tourism. Anatolia 2021, 32, 126-127. [CrossRef]

5. Martin, L.; Ricci, M. Le Tourisme Littoral Post-COVID-19: Renouveau des Pratiques Touristiques? (Post-COVID-19 Coastal Tourism: A Renewal of Tourism Practices?). Téoros. 2020. Available online: http://journals.openedition.org/teoros/5902 (accessed on 3 May 2021).

6. UNWTO. Global Guidelines to Restart Tourism; UNWTO: Madrid, Spain, 2020.

7. Serrano, M. Nacen Los Destinos " $4 S^{\prime}$ ! (Destinations " $4 S^{\prime}$ are Born!). Hosteltur. 2020. Available online: https://www. hosteltur.com/comunidad/nota/022158_nacen-los-destinos-4s.html\#: \{\}:text=Es\%20el\%20momento\%20para\%20trabajar, que $\% 20$ priorizar $\%$ C3\%A1\%20el\%20\%E2\%80\%9Cnuevo\%20turista (accessed on 29 May 2021).

8. La Moncloa. Turismo Presenta su Estrategia de Sostenibilidad Para Los Destinos Con Una Inversión Pública de 1.905 Millones. (Tourism Presents Its Sustainability Strategy for Destinations with a Public Investment of 1.905 Million). Available online: https://www.lamoncloa.gob.es/serviciosdeprensa/notasprensa/industria/Paginas/2021/190421-sostenibilidad.aspx (accessed on 5 June 2021).

9. Díez, D. ‘La Diversificación Turística Como Estrategia Clave Para la Reactivación de Destinos Consolidados del Litoral: La Reinvención de Cullera (España)', Seminario Internacional Renovación y Reestructuración de Destino Turísticos Consolidados del Litoral, 24-25 Noviembre de 2011. Alicante. Available online: http://rua.ua.es/dspace/handle/10045/20812 (accessed on 13 July 2021).

10. Santos, E.L.; Fernández, A. El litoral turístico español en la encrucijada: Entre la renovación y el continuismo. Cuadernos de Turismo 2010, 25, 185-206.

11. Antón, S. De los procesos de diversificación y cualificación a los productos turísticos emergentes. Cambios y oportunidades en la dinámica reciente del turismo litoral. Papeles de Economía Española 2004, 102, 316-332.

12. Vera, J.F.; Baños, C. ‘Renovación y reestructuración de los destinos turísticos consolidados del litoral: Las prácticas recreativas en la evolución del espacio turístico'. Boletín de la Asociación de Geógrafos Españoles 2010, 53, 329-353.

13. Antón, S. Dinámicas de reestructuración de los destinos turísticos litorales del mediterráneo. Perspectivas y condicionantes. Proceedings of XIII Congreso Internacional de Turismo Universidad y Empresa: Renovación de destinos turísticos consolidados, Valencia, Spain, 6-8 May 2010; 2011.

14. Cànoves, G.; Prat, J.M.; Blanco, A. Turismo en España, más allà del sol y la playa. Evolución recinte y cambios en los destinos de litoral hacia un turismo cultural. Boletín de la Asociación de Geógrafos Españoles 2016, 71, 431-454. [CrossRef]

15. Priestley, G. Sostenibilidad, ciclo de vida y desarrollo de los destinos turísticos: Hacia un nuevo modelo del turismo español; Priestley, G., Llurdñes, J.C., Eds.; Estrategia y gestión del turismo en el municipio. Escola Universitària de Turisme i Direcció Hotelera-UAB: Bellaterra, Spain, 2007.

16. Vera, J.F. Análisis Territorial del turismo y planificación de destinos turísticos; Tirant Humanidades: Valencia, Spain, 2013.

17. Simancas Cruz, M. Gobernabilidad territorial y relaciones de poder en espacios turísticos: Los conflictos derivados de las políticas públicas de renovación de los destinos turísticos consolidados de litoral. Anales de Geografía de la Universidad Complutense 2018, 38, 435-460. [CrossRef]

18. Gutiérrez, M. El Negocio de Sol y Playa Inicia su Reconversión Para Superar la Crisis (The Sun and Beach Business Begins Its Conversion to Overcome the Crisis), La Vanguardia 2021. Available online: https:/ /www.lavanguardia.com/economia/202103 22/6603525/turismo-espana-pandemia-covid-negocio-impacto-crisis.html (accessed on 30 May 2021).

19. Observatori del Treball i Model Productiu. Informe: Turisme. Resum de Resultats Anuals del Turisme. Any 2019, Catalunya (Report: Tourism. Summary of Annual Tourism Results. Year 2019, Catalonia). Generalitat de Catalunya 2020. Available online: https:/ / observatoritreball.gencat.cat/web/.content/02_-_ambits_tematics/turisme/09_-_resultats_anuals/2019/arxius / Resum_resultats_anuals_2019.pdf (accessed on 3 February 2021).

20. HOSTELTUR. El Turismo catalán Pierde 15.000 Millones por la COVID (Catalan Tourism Loses 15,000 Million Euros due to COVID). 2020. Available online: https:/ / www.hosteltur.com/141365_el-turismo-catalan-en-una-situacion-dramatica-pierde-15 000-millones.html (accessed on 30 May 2021).

21. Smith, M.K.; Diekmann, A. Tourism and wellbeing. Ann. Tour. Res. 2017, 66, 1-13. [CrossRef]

22. Cornelia, V.; Pforr, C. Wellness Tourism: A Destination Perspective; Routledge: London, UK, 2017.

23. World Tourism Organization and European Travel Commission. Exploring Health Tourism; UNWTO eLibrary: Madrid, Spain, 2018.

24. Global Wellness Institute. The Global Wellness Tourism Economy Report; Global Wellness Institute: Miami, FL, USA, 2018.

25. Global Wellness Institute. Understanding Wellness: Opportunities E Impacts of the Wellness Economy for Regional Development; Global Wellness Institute: Miami, FL, USA, 2019.

26. Bell, S.L.; Phoenix, C.; Lovell, R.; Wheeler, B.W. Seeking everyday wellbeing: The coast as a therapeutic landscape. Soc. Sci. Med. 2015, 142, 1-13. [CrossRef] [PubMed] 
27. Bratman, G.N.; Anderson, C.B.; Berman, M.G.; Cochran, B.; de Vries, S.; Franders, J.; Folke, C.; Frumkin, H.; Gross, J.J.; Hartig, T.; et al. Nature and mental health: An ecosystem service perspective. Sci. Adv. 2019, 5, eaax0903. [CrossRef] [PubMed]

28. de Vries, S.L.; Verheij, R.A.; Groenewagen, P.P.; Spreeuwenberg, P. Natural environments-healthy environments? An exploratory analysis of the relationship between greenspace and health. Environ. Plan. A 2003, 35, 1717-1731. [CrossRef]

29. Hartig, T.; Mitchell, R.; de Vries, S.; Frumkin, H. Nature and health. Annu. Rev. Public Health 2014, 35, 207-228. [CrossRef] [PubMed]

30. Michopoulou, E.; Niccolini, F.; Taff, B.D.; Clarke, A. (Eds.) Tourism, Health, Wellbeing and Protected Areas; Azara, I.; CABI: Wallingford, UK, 2018.

31. Kelly, C. 'I Need the Sea and the Sea Needs Me': Symbiotic coastal policy narratives for human wellbeing and sustainability in the UK. Mar. Policy 2018, 97, 223-231. [CrossRef]

32. Kelly, C. Beyond 'a trip to the seaside': Exploring emotions and family tourism experiences. Tour. Geogr. 2020. [CrossRef]

33. Sánchez-Pérez, M.; Terán-Yépez, E.; Marín-Carrillo, M.B.; Marín-Carrillo, G.M.; Illescas-Manzano, M.D. La COVID-19 y el sector turístico en España: Impacto sobre el comportamiento del consumidor turístico (COVID-19 and the Tourism Sector in Spain: Impact on Tourism Consumer Behavior); Universidad de Almería: Almería, Spain, 2021.

34. EXCELTUR. Solytur. Nuevos Paradigmas Competitivos en Los Destinos de Sol y Playa. Presentación de Resultados del Informe SOLYTUR en el Marco de los Fondos Next Generation de la UE (Solytur. New Competitive Paradigms in Sun and Beach Destinations. Presentation of the Results of the SOLYTUR Report within the Framework of the EU Next Generation Funds). 2021. Available online: https: / www.youtube.com/watch?v=NEKuWgYKKAo (accessed on 30 May 2021).

35. Voigt, C.; Pforr, C. Wellness Tourism; Routledge: New York, NY, USA, 2013; Volume 81, pp. 84-85.

36. Moreno, A.; Léon, C.; Fernández, C. 'Revalorización del Producto Turístico a Través del Turismo de Salud', Simancas, M.; Hernández, R.; Padrón, N. (Coord.) Turismo pos-COVID-19. Reflexiones, Retos y Oportunidades. Cátedra de Turismo CajaCanarias-Ashotel-Universidad de La Laguna. 2020. Available online: https:/ /doi.org/10.25145/b.Turismopos-COVID-19.2 020 (accessed on 30 May 2021).

37. EXCELTUR. Solytur.19. Monitor de Competitividad Turística de los Destinos del "Sol y Playa" (Solytur.19. Monitoring the Tourist Cmpetitiveness of Spanish Sun and Beach Destinations); EXCELTUR eLibrary: Madrid, Spain, 2021.

38. Obiol, E.; Ferrandis, A. 'Gandia y sus prácticas de renovación turística', Seminario Internacional Renovación y reestructuración de destino turísticos consolidados del litoral. Alicante 2011.

39. Santos, R.; Antón, S.; Saladié, O. Discontinuidades y limitaciones de los últimos planes turísticos de España en relación a la sostenibilidad ambiental del turismo de sol y playa'. Cuadernos de Turismo 2017, 40, 599-626. [CrossRef] 